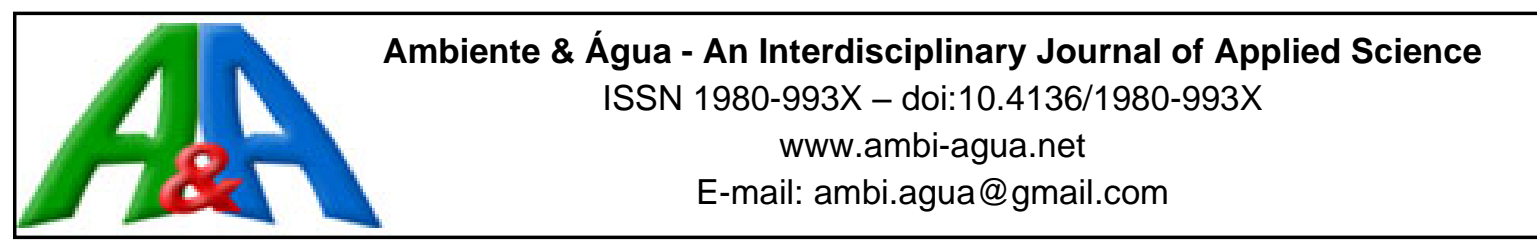

\title{
Effects of rainwater intrusion on an activated sludge sewer treatment system
}

\author{
ARTICLES doi:10.4136/ambi-agua.2497
}

Received: 23 Nov. 2019; Accepted: 23 Mar. 2020

\section{Diogo Botelho Correa de Oliveira ${ }^{1 *}$; Willames de Albuquerque Soares ${ }^{2}$ (D); Marco Aurélio Calixto Ribeiro de Holanda ${ }^{3}$ id}

\author{
${ }^{1}$ Programa de Pós-Graduação em Engenharia Civil. Universidade de Pernambuco (UPE), Rua Benfica, ${ }^{\circ} 455$, \\ CEP: 50720-001, Recife, PE, Brazil. \\ ${ }^{2}$ Escola Politécnica de Pernambuco. Departamento de Física de Materiais. Universidade de Pernambuco (UPE), \\ Rua Benfica, n 455, CEP: 50720-001, Recife, PE, Brazil. E-mail: was@ poli.br \\ ${ }^{3}$ Programa de Pós-Graduação em Engenharia Civil. Escola Politécnica de Pernambuco (POLI-UPE). \\ Universidade de Pernambuco (UPE), Rua Benfica, ${ }^{\circ}$ 455, CEP: 50720-001, Recife, PE, Brazil. \\ E-mail: holandamacr@yahoo.com.br \\ *Corresponding author. E-mail: diogobotelhocorrea@gmail.com
}

\begin{abstract}
Effluent collection and stormwater management make use of different drainage systems, which should remain unconnected with one another. If stormwater drains into sewage collection systems, it often causes changes in effluent quality indicators at sewage treatment plants. This study sought to quantify the changes caused by rain in a Wastewater Treatment Plant (WWTP) located in Paulista, PE, which uses the activated sludge system. Accordingly, changes in $\mathrm{pH}$, temperature, BOD, and treatment efficiency at the inlet and outlet, as well as inlet flow were analyzed on dry and rainy days at the plant, which has a sewage capacity of $400 \mathrm{~L} \mathrm{~s}^{-1}$. The input volume was found to be greater than the design flow of the station, about $25 \%$. With this, some relevant operational controls were identified, such as temporarily shutting down sewage pumping stations in order to maintain full operation of the system and avoid overload. The $\mathrm{pH}$ increases slightly in alkalinity, about 0.3 , but this does not interfere with the treatment process. The temperature of the influent on rainy days is about 3 to 5 degrees cooler, depending on the intensity of the event. Using the $\mathrm{T}$ and $\mathrm{Z}$ tests, it was possible to identify that BOD concentrations in the influent and the effluent were not significantly different (uneq. var. t: 1.18 $>0.26$ and uneq var. z: $0.71>0.48$, respectively), and the organic load removal efficiency was maintained, contrary to what is expected with other, more simple types of treatment.
\end{abstract}

Keywords: absolute separator system, activated sludge, effluent treatment.

\section{Efeitos da intrusão de águas pluviais em um sistema de tratamento de esgotos por lodo ativado}

\section{RESUMO}

A coleta de afluentes e o manejo de águas pluviais são canalizadas em sistemas distintos, não devendo haver comunicação entre si, pois quando isto acontece é comum identificar alterações nos indicadores de qualidade dos efluentes nas estações de tratamento de esgotos. Deste modo, objetiva-se quantificar as alterações causadas pela chuva no tratamento de esgoto 
sanitário, os quais utilizam o sistema de lodo ativado. Para uma ETE, localizada no município de Paulista, PE, com capacidade de $400 \mathrm{~L} \mathrm{~s}^{-1}$, utilizando sistemas de lodos ativados, foram analisadas as alterações, na entrada e na saída do sistema para os: $\mathrm{pH}$, temperatura, $\mathrm{DBO} \mathrm{e}$ eficiência de tratamento, além da vazão de entrada, entre dias considerados secos e chuvosos. Foi constatado que o volume de entrada é incrementado em média de $25 \%$ da vazão de projeto de dimensionamento da estação. Com isto, alguns controles operacionais relevantes foram identificados, como a paralização temporária de estações elevatórias de esgoto, visando manter o pleno funcionamento do sistema, evitando sua sobrecarga. $\mathrm{O} \mathrm{pH}$ sofre leve aumento na alcalinidade, cerca de 0,3 , mas sem interferir no processo de tratamento. Já a temperatura do afluente em dias chuvosos sofre redução de 3 a $5 \mathrm{~K}$, dependendo do evento. Utilizando os testes $\mathrm{T}$ e Z, foi possível identificar que não houve alterações significativas (uneq. var. t: $1.18>0.26$ e uneq var. z: $0.71>0.48$, respectivamente) nas concentrações de DBO, tanto no efluente quanto no afluente, e a eficiência de remoção de carga orgânica foi mantida, ao contrário do que se espera em outros tipos de tratamento mais simples.

Palavras-chave: lodos ativados, sistema separador absoluto, tratamento de efluentes.

\section{INTRODUCTION}

Basic sanitation encompasses essential systems that are of great relevance to the population. Its activities include water supply and treatment for use and consumption, sewage collection and treatment, urban drainage, including stormwater management, urban collection and sanitation, and control of pests and pathogens. Sewage collection and treatment are key to reducing pollution and contamination of water bodies and soil, and improving the quality of animal and plant life. The World Health Organization (WHO) estimates that each $\mathrm{R} \$ 1.00$ invested in basic sanitation is equivalent to $\mathrm{R} \$ 4.00$ spent on healthcare due to problems arising from lack of sanitation (Costa et al., 2018).

According to Jamwal et al. (2015), sewage systems can be differentiated with regard to their interaction, or lack thereof, with the rainwater collection system. This distinction is influenced mainly by the geographical position and economic situation of the drainage basin. These systems can be divided into: combined (or unitary) systems, mixed (or partial) separator systems, and absolute separator systems. Combined systems perform better and are more common in more affluent, subtropical regions (such as Western Europe) where all rainwater discharge is directed to sewers. In tropical areas, where precipitation volume is more significant, absolute separators or mixed separators can be used. The use of mixed separator systems depends on the deployment system or project adopted, combining the needs and benefits of each system.

In the absolute separator system, sewage must be collected, transported, and treated separately from rainwater, but in practice this does not happen. In fact, there are connections between the two systems, either through clandestine connections or through accidental interceptions. In the case of sanitary sewage systems, this can happen in several ways: rain infiltration into the soil that is consequently redirected to the sewage system, surface contributions caused by rainwater entering devices such as manholes, or through irregular contributions such as direct connections with the public drainage network or with building rainwater drainage pipes in sewage collection systems (Ribeiro and Peixoto, 2018).

With the increase of influent sewage flow through the rainwater system, various harmful changes occur. Overloading of the collection pipes (which are not sized to absorb this increase) and at the entrances of Wastewater Treatment Plants (WWTPs) can be from $40 \%$ to 300\% higher than on days without rainfall, depending on the precipitation intensity and the size of the basin (Mines et al., 2007; Ribeiro and Peixoto, 2018). 
Regardless of the collection method (absolute separator, mixed, or combined), the different treatment types react in various ways to this increased flow, especially the most rudimentary, such as stabilization ponds, septic tanks, Imhoff tanks with secondary anaerobic or even biological filter systems. In general, systems that are highly dependent on primary settling treatments can be said to be most influenced by this parasitic contribution (Tonetti et al., 2012). Saliba and von Sperling (2017) point out that, although the treatment efficiency (organic load removal) in more advanced treatment systems (such as activated sludge) is not affected, during periods of rain there is a noticeable increase in operating costs as well as a reduced sewage treatment detention time.

Unlike qualitative studies in this context, quantitative studies are still scarce in Brazil, especially with regard to large systems. Therefore, this study aimed to quantify the changes that occur due to rainfall interferences in sewage collection systems, taking into account the differences in effluent quality indicators between dry and rainy days for a large capacity Wastewater Treatment Plants that uses an activated sludge treatment system, taking into consideration the following input and output indicators: temperature, $\mathrm{pH}, \mathrm{BOD}$, and organic load removal efficiency, as well as a historical comparison of the inflows at the plant.

\section{MATERIALS AND METHODS}

The Janga WWTP has been operational since 1981, and has a flow rate of around $400 \mathrm{~L} \mathrm{~s}^{-1}$. It was designed to serve 451,900 inhabitants. It currently uses a secondary activated sludge treatment system due to the need for high efficiency and low availability of physical space (relative to project demand). The sanitary sewer system basin of Janga, which comprises the entire sub-basin system, is located in the municipalities of Olinda and Paulista, which are part of the Recife Metropolitan Area. It is noteworthy that not all areas within the basin have sewage collection or even water supply. The sanitary system, shown in Figure 1, contains the Janga (blue) and Olinda (yellow), sub-basins, which are approximately $2206 \mathrm{~km}^{2}$ and $2101 \mathrm{~km}^{2}$, respectively. After treatment, the effluent is directed to the receiving body, flowing into the Timbó River.

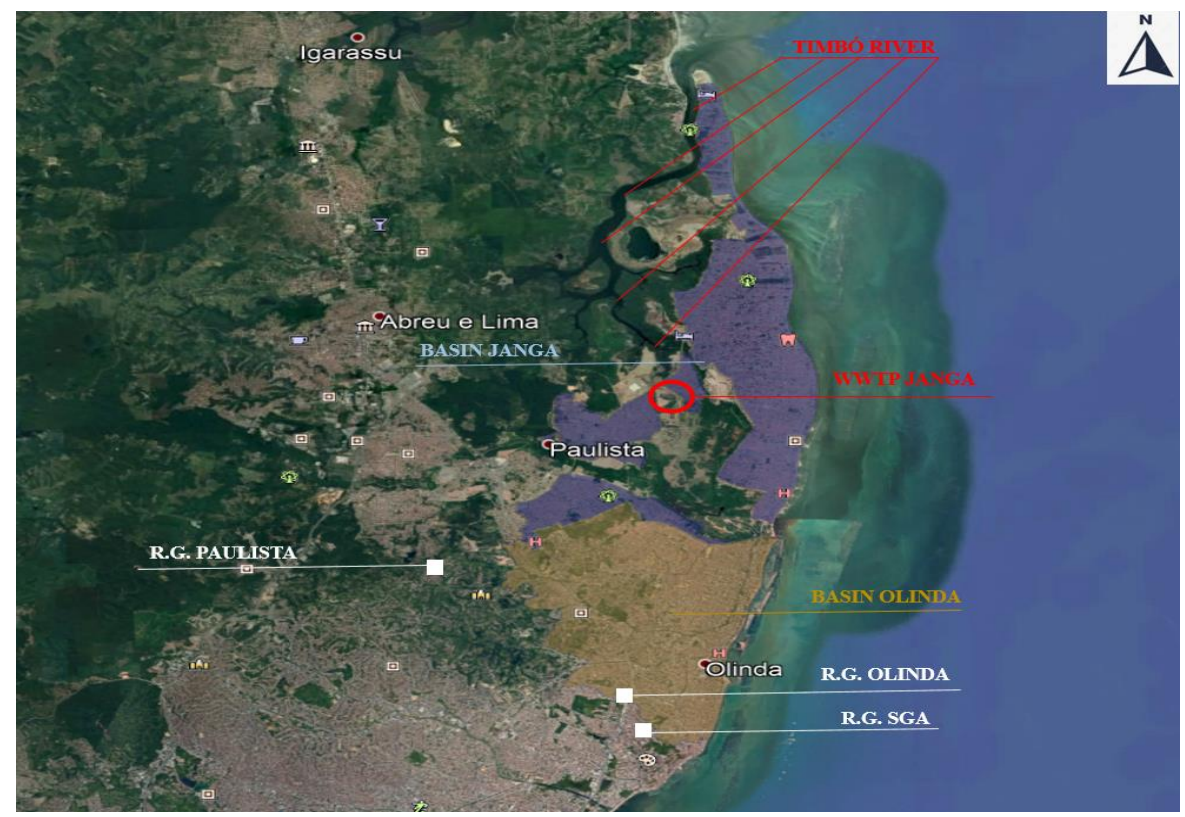

Figure 1. Basins in the Janga treatment plant sewage system and its rainfall stations: Paulista, Academia Santa Gertrudes (SGA), and Olinda; and the effluent receiving body (Timbó River).

Source: Adapted from Google Earth (2019). 
The Janga sanitary sewer system is located on the coast of Pernambuco, which has a hot and humid Ams (Koppen classification) tropical climate, with average annual temperatures between $298 \mathrm{~K}$ and $303 \mathrm{~K}$. The months with the highest temperatures are October, November, and December. During the winter period in June, July, and August, the temperature drops significantly, averaging 295K (Wanderley et al., 2018). The Pernambuco coast has an average annual rainfall of $2050 \mathrm{~mm}$, being the area with the highest rainfall in northeastern Brazil, where the months of October through February are very dry with the rainy season beginning in March. The highest rainfall is usually recorded in June, with an average accumulation of more than 600 mm (Holanda and Soares, 2019).

To carry out the study, analytical data of effluent quality was used, supplied by the Pernambucan Sanitation Company (Compesa), the current sanitation services concessionaire in Pernambuco. Data collections are performed once a month to verify compliance with legislation and other environmental agencies. For this study, effluent temperature, $\mathrm{pH}$ (Thermo Scientific Orion Star A221, APHA et al., 2012), and BOD were measured (Respirometric Method, APHA et al., 2012) at the treatment plant inlet and outlet, as well as the BOD removal rate, necessary to evaluate treatment efficiency, and the inlet flow rate, used in the rainfall data. For this, data provided by the Pernambuco Water and Climate Agency (APAC) were necessary. These data were obtained from three stations, two in Olinda (Olinda and Academia Santa Gertrudes) and one in Paulista (Paulista), which are the most suitable for this study because of their geographical position.

When the rainfall data showed the highest precipitation rates, comparisons were made between the amount of effluent collected at the WWTP on that day and on the day before. For the Janga Basin, the Paulista station was considered, and for the Olinda Basin, the arithmetic mean of the Olinda and Academia Santa Gertrudes stations was used to obtain the rainfall indexes. To consolidate the data, a weighted average was used, taking into account the area of the basins in relation to their respective rainfall amounts. The Thiessen method was not used, because the graphic division would leave most of the system influenced by only the Paulista station, and both Olinda stations would have minimal influence on the process.

According to Wanderley et al. (2018), a day with very heavy rainfall in Recife is characterized as a day when rainfall is greater than or equal to $25 \mathrm{~mm}$, while moderate rainfall is a value between 15 and $25 \mathrm{~mm}$. Days with precipitation less than $15 \mathrm{~mm}$ can be considered as dry or low rainfall. The analyzed data was then separated in order to quantify cases based on daily accumulated volume. Six of the data collection days had rainfall greater than $15 \mathrm{~mm}$, as shown in Table 1.

Table 1. Rainfall for the sanitary sewer system under study on rainy days (*) and dry days.

\begin{tabular}{cccccc}
\hline Event date & $\begin{array}{c}\text { Precipitation } \\
(\mathrm{mm})\end{array}$ & Event date & $\begin{array}{c}\text { Precipitation } \\
(\mathrm{mm})\end{array}$ & Event date & $\begin{array}{c}\text { Precipitation } \\
(\mathrm{mm})\end{array}$ \\
\hline 03/DEC/2018 & 0.00 & $08 / \mathrm{FEB} / 2018$ & 0.00 & $12 / \mathrm{APR} / 2017^{*}$ & 52.21 \\
08/NOV/2018* & 25.89 & $02 / \mathrm{JAN} / 2018$ & 0.00 & $27 / \mathrm{MAR} / 2017$ & 6.40 \\
01/OCT/2018 & 0.00 & $04 / \mathrm{DEC} / 2017$ & 0.02 & $07 / \mathrm{JUL} / 2016$ & 4.44 \\
20/SEP/2018 & 0.08 & $06 / \mathrm{NOV} / 2017$ & 0.07 & $02 / \mathrm{JUN} / 2016$ & 0.14 \\
22/AUG/2018 & 2.40 & $02 / \mathrm{OCT} / 2017$ & 0.16 & $19 / \mathrm{MAY} / 2016$ & 0.16 \\
12/JUL/2018 & 2.03 & $05 / \mathrm{SET} / 2017$ & 3.91 & $19 / \mathrm{APR} / 2016$ & 9.41 \\
05/JUN/2018 & 3.02 & $03 / \mathrm{AUG} / 2017$ & 4.28 & $09 / \mathrm{MAR} / 2016$ & 0.00 \\
02/MAY/2018* & 15.93 & $03 / \mathrm{JUL} / 2017 *$ & 25.00 & $01 / \mathrm{FEB} / 2016$ & 0.97 \\
16/APR/2018* & 32.45 & $01 / \mathrm{JUN} / 2017 *$ & 22.38 & $04 / \mathrm{JAN} / 2016$ & 0.00 \\
08/MAR/2018 & 3.05 & 12/MAY/2017 & 3.26 & & \\
\hline
\end{tabular}

Source: APAC, 2019. 
The period from 2016 to 2018 was considered for data analysis. During the first year of the study there were external interferences that prevented flow measurements at the WWTP, except in April and June, as the unit was undergoing adjustments to its physical structure to allow for installation of an ultrasonic flowmeter. From May 2016 to January 2017, intensive recoveries were carried out on the unit (civil adjustments, structural restoration, and equipment modernization), not allowing samples collected from August to December 2016 and January 2017, making analysis of effluent in this period impossible. To maintain consistency in the efficiency data (organic load removal), only data available after December 2016 were considered. The principal indicators to be analyzed, established in CONAMA Resolution 430, are: $\mathrm{pH}$, which should remain between 5 and 9; temperature below 313K, and BOD with a maximum limit of $120 \mathrm{mg} \mathrm{L}^{-1}$ or a minimum organic load removal of $60 \%$ (CONAMA, 2011). Data were divided into two groups, according to the categorization of the collection days (rainy and dry). Among these samples, the Anderson-Darling and Shapiro-Wilk normality adherence tests were performed, at a significance level of 5\%, in addition to the T-test, for data recorded from January 2017, and the Z test, for records between January and February 2016 and from January 2017 to December 2018, in order to identify significant variations between rainy and dry days for the studied parameters ( $\mathrm{pH}$, temperature, and BOD). For both tests, the Past was used (Hammer et al., 2001).

\section{RESULTS AND DISCUSSION}

A comparison of the inlet flow rates, $\mathrm{pH}$, temperature, BOD and efficiency of the treatment station was performed on rainy and dry days, in order to identify any significant differences that would quantify the influence of rainwater on the sewage system collection basin.

In Figure 2, it is possible to observe the instantaneous flow rate on the collection days, the average flow rate for dry days, the threshold separating dry and rainy days, and the daily precipitation. The average flow rate of the WWTP was $366 \mathrm{~L} \mathrm{~s}^{-1}$ on dry days and approximately $464 \mathrm{~L} \mathrm{~s}^{-1}$ on rainy days, with this difference representing an average increase of $24.5 \%$ in the projected flow rate, i.e. an increase of $98 \mathrm{~L} \mathrm{~s}^{-1}$, a value that considerably alters the project design and sizing of the WWTP. For 2016, only the April 19 and June 2 records were considered, due to the structural renovation of the WWTP and the installation of the new flowmeter. From January 2017 on, all data were considered, except for 12/APR/2017, 06/JAN/2017, and 06/MAY/2018, which presented highly unusual values, with precipitation of approximately 52 $\mathrm{mm}, 22 \mathrm{~mm}$, and $3 \mathrm{~mm}$, respectively (two rainy days and one dry day) and flow rates of $182 \mathrm{~L}$ $\mathrm{s}^{-1}, 63 \mathrm{~L} \mathrm{~s}^{-1}$, and $8 \mathrm{~L} \mathrm{~s}^{-1}$. The first two dates have low flow rates in relation to the others registered and the third has a flow of almost zero. This is explained by the operational control of the WWTP, whereby booster pumps are deactivated so as not to overload the sewage treatment design flow on days of major upstream contributions (whether influenced by rain or not). These values were therefore disregarded when calculating the average inlet flow.

According to Branco (2015), this procedure is common and necessary for the proper functioning of the treatment system, by not significantly changing the operation of the station. These procedures are defined by the control of the incoming flow at the WWTP, the monitoring of the operation of all treatment components, the maintenance of the aeration tanks, decanters, pumps, and equipment, and the disposal of excess sludge.

Agreeing with the results found, several studies (Shatat and Najar, 2011; Branco, 2015; Saliba and von Sperling, 2017; Ribeiro and Peixoto, 2018) show that the interference of rainfall in sewers and sewage treatment plants directly influence various aspects of the operation of the sanitary sewage system. The increase of inflow on stormy and high rainfall days is strongly correlated and may be up to three times higher than that recorded on dry days, depending on the size of the basin in which it is located. Concentrations of suspended solids and $\mathrm{NH}_{3}$ can be as much as 10 and 1.2 times greater, respectively. Due to the increase in flow rate, the studies 
mentioned above suggest that BOD concentration is diluted by the large increase in water volume, generating negative consequences, such as a reduction in detention time and a reduction in treatment efficiency because the organic input load is lower (Mines et al., 2007).

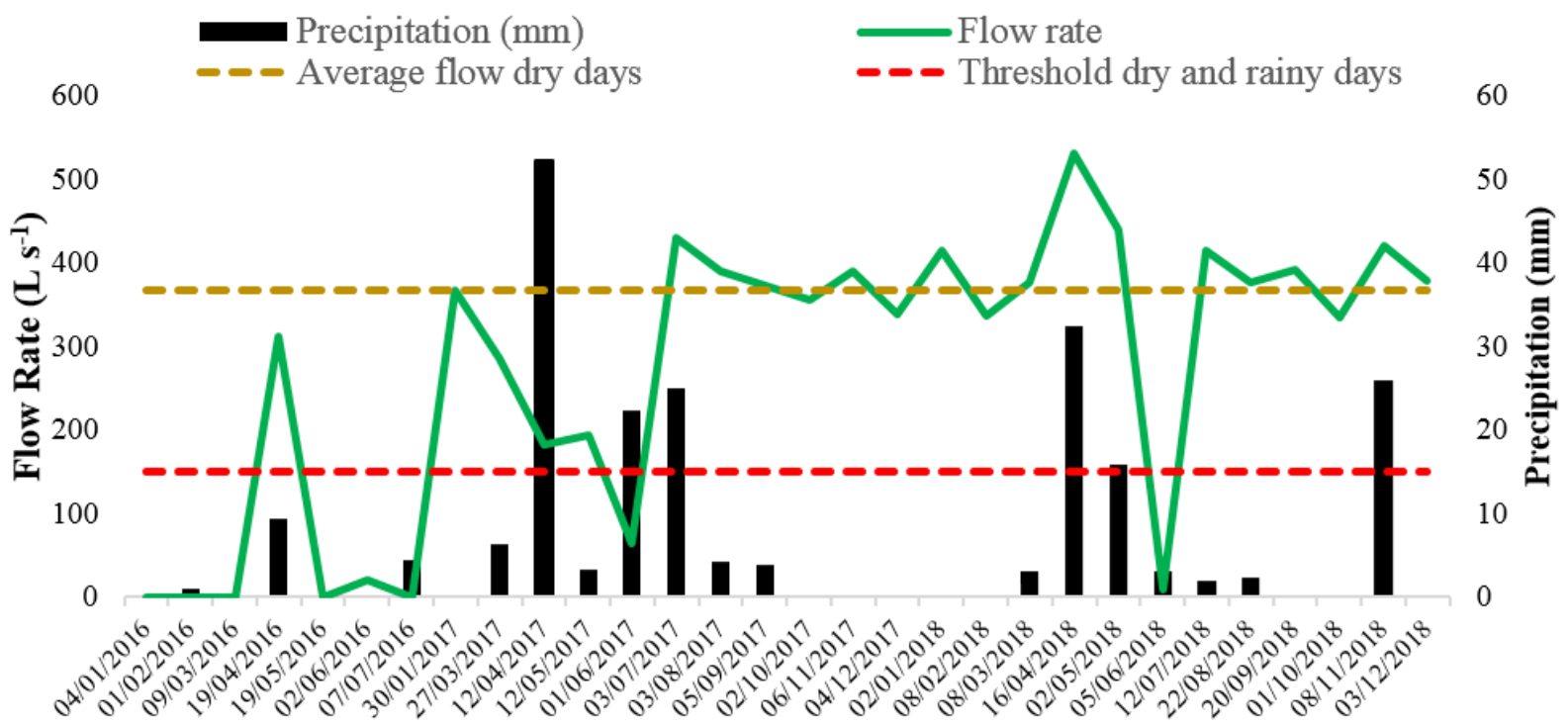

Time (dd/mm/yyyy)

Figure 2. Input Flow, Precipitation, and Average Flow for the study days.

The other values recorded range from $311 \mathrm{~L} \mathrm{~s}^{-1}$ (April 2016) to $430 \mathrm{~L} \mathrm{~s}^{-1}$ (July 2017) for dry days and from $421 \mathrm{~L} \mathrm{~s}^{-1}$ to $530 \mathrm{~L} \mathrm{~s}^{-1}$ for rainy days. According to Figure 2, flow data tends to stabilize after July 2017 (except for June 2018), settling near the dry day average at around $370 \mathrm{~L} \mathrm{~s}^{-1}$.

Figure 3 shows the boxplots for the $\mathrm{pH}$, temperature, and BOD indicators of the inlet and outlet flows of the Janga WWTP effluent on dry and rainy days.

The $\mathrm{pH}$ values indicated that dry days had more acidic effluent than rainy days, a difference of about 0.3 for both average and median (Piratoba et al., 2017). From the boxplot, it is possible to see that the influent is more acidic than the effluent, due to the sewage treatment itself, which in this case is aerobic, with a tendency to become more alkaline. Two outliers during the rainy season were identified, and these were disregarded in the statistical analysis. The $\mathrm{pH}$ on rainy days was numerically higher, and there was less dispersion between quartiles, both at the entrance and exit of the station, and it can be inferred that the effluent acidity was slightly reduced due to the intrusion of rainwater, but without changing the colony of bacteria present in the sewage (Zoppas et al., 2016).

The values found for effluent $\mathrm{pH}$ are in agreement with results from other studies (Gois et al., 2016; Senturk and Buyukgungor, 2017), where this value starts out as acidic at the beginning of the treatment process and naturally evolves to the alkaline phase. If it returns to the acid phase, this may indicate potential problems with the devices that make up the WWTP. The $\mathrm{pH}$ value normally varies from 6 to 8 in its natural state, and may change depending on the type of treatment (Braile and Cavalcanti, 1993). In anaerobic treatment systems, neutral or alkaline sewage is more common, as this environment favors the fermentation and disintegration of organic matter. For better oxygen production as a result of aerobic treatment, slightly alkaline $\mathrm{pH}$ values of around 8 are most suitable. This process is also beneficial for the recipient water body, which is generally a slightly acidic medium due to anthropogenic activities. Any values very far from neutral $\mathrm{pH}$ may cause problems for biomes in the environment (Gois et al., 2016; Senturk and Buyukgungor, 2017). 


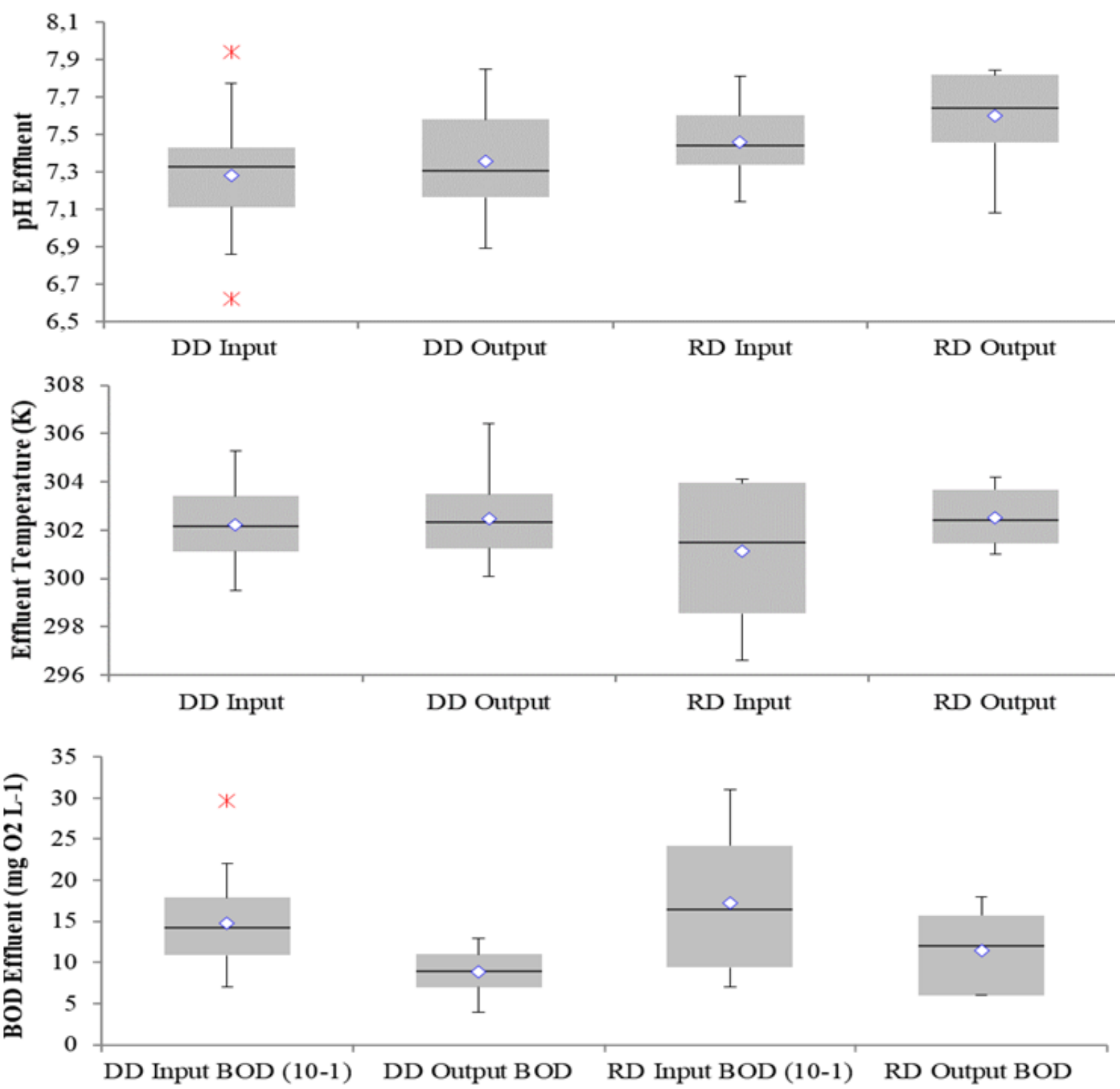

Figure 3. Boxplot of the evaluated indicators for the treatment of effluent at the Janga WWTP on dry days (DD) and rainy days (RD), from 2016 to 2018. Legend: asterisk - outliers, upper boundary of rectangle - 3rd quartile, diamond - average, straight line - median, lower boundary of rectangle - 1st quartile.

For this study, the temperatures recorded at the inlet and outlet on dry days and at the outlet on rainy days are not significantly different. Their averages and medians are close to $302 \mathrm{~K}$ and the first and third quartiles range from $301 \mathrm{~K}$ to $303 \mathrm{~K}$. This is because of the low temperature variation on dry days (typical of the region) and the outflow from the treatment process, which regulates temperature due to its release into the recipient water body. Influent data on rainy days shows significantly reduced temperature, with the average and median near $301 \mathrm{~K}$ and the 1 st and 3rd quartiles close to $299 \mathrm{~K}$ and $303 \mathrm{~K}$. In this case, the influent temperature is influenced more strongly by rainfall contributions. As the rainfall is colder than the sewage, this provides additional proof of parasitic contributions in the collection system.

The temperature of the water directly influences the activities of the microorganisms present in the sewage, such that BOD removal is directly proportional to it, showing considerable differences in treatment between the winter and summer periods, where the temperature variations are significant. Shatat and Najar (2011) identified that heating of the 
influent can improve the efficiency of the process, where temperatures near $303 \mathrm{~K}$ improve the organic load removal and temperatures from $313 \mathrm{~K}$ to $323 \mathrm{~K}$ show an improvement in the removal of other elements such as nitrate, ammonia, phosphates, and suspended solids. This factor is better utilized in the treatment of industrial wastes, due to the different composition when compared with domestic waste (Ahsan et al., 2005).

It is important to note that sewage heating methodologies have a considerable cost of both implementation and operation, and also requires a final cooling process, so it can be released into the receiving water body at ambient temperature to avoid potential environmental impacts (Shatat and Najar, 2011). This is still a distant reality for Brazilian WWTPs. Although most of the Brazilian treatment systems implemented since the 1990s use activated sludge and an upflow anaerobic sludge blanket (UASB), current investments are still directed towards the implementation of collection networks and new treatment plants, not for the improvement of existing ones (Chernicaro et al., 2015). Thus, the use of techniques aimed at improving existing treatment plants is limited by the lack of financial resources.

The average BOD of the influent on dry days was $150.18 \mathrm{mg} \mathrm{L}^{-1}$ of $\mathrm{O}_{2}$, while on rainy days it was $172.00 \mathrm{mg} \mathrm{L}^{-1}$ of $\mathrm{O}_{2}$, a difference of less than $13 \%$ compared to the average of the highest concentration. The BOD values for effluent exit had an average of $9.65 \mathrm{mg} \mathrm{L}^{-1}$ of $_{2}$ on dry days and $11.50 \mathrm{mg} \mathrm{L}^{-1}$ of $\mathrm{O}_{2}$ for rainy days. The increase in flow due to the combination of sewage and rainwater caused the organic load concentrations to slightly increase, both at the entrance and exit of the system, and caused increased variability of this parameter in the effluent, according to the boxplots in Figure 3. The incoming BODs are widely dispersed, especially in the 3 rd quartile values, ranging from 50 to $310 \mathrm{mg} \mathrm{L}^{-1}$ of $\mathrm{O}_{2}$ compared to the average, which is $145 \mathrm{mg} \mathrm{L}^{-1}$ of $\mathrm{O}_{2}$, corroborating with the study by Mahapatra et al. (2013).

Normally BOD values for the influent increase at the onset of rainfall events due to the dragging of contaminants present in the environment and then reduce over time due to increased flow and dilution of concentration, significantly affecting treatment efficiency, which is impaired because it becomes more difficult to minimize output BOD (Ávila et al., 2013).

The efficiency of effluent treatment at the Janga WWTP can be seen in Figure 4, where its analysis considers two distinct periods: from March 2016 to December 2016, and from January 2017 to December 2018. The first covers the time period of the structural remodeling and interference in the treatment processes, when disagreements occurred with CONAMA regarding the release of effluents, other than at the February 2016 collection date, but with due justification and environmental license. In this first interval, it is also possible to correlate the low-efficiency months with the superior dispersion of BOD output data (correlation between Figures 3 and 4), where high output values ranging from 30 to $90 \mathrm{mg} \mathrm{L}^{-1}$ of $\mathrm{O}_{2}$, considerably increasing the average, which rose from 9.65 to $26.92 \mathrm{mg} \mathrm{L}^{-1}$ of $\mathrm{O}_{2}$, an increase of almost $279 \%$ over the period from January 2017.

In the following months, the efficiency values measured at the station demonstrated regularity, even achieving organic load reductions above 90\% (except on 3 occasions: 12/APR/2017, 03/JUL/2017, and 06/NOV/2017). Considering the entire study period (January 2016 to December 2018), on dry days, the unit's average efficiency was $84.25 \%$, while on rainy days, the average was $85.10 \%$. Disregarding the period in which the WWTP was undergoing the structural recuperation process, these figures increase to $93.10 \%$ and $93.20 \%$, respectively. Between January 2017 and December 2018, there were few variations in efficiency, and it can be inferred that during the rainy season (marked in red by Figure 4), this indicator did not significantly change for sewage treatment at the Janga WWTP.

Using the Anderson-Darling and Shapiro-Wilk normality adherence tests at a significance level of 5\%, two data groups were evaluated: the first referring to the period before and after the structural renovation (January and February 2016 and from January 2017 to December

Rev. Ambient. Água vol. 15 n. 3, e2497 - Taubaté 2020 
2018) and second group of data which is available after the completion of the recuperation of the WWTP, from January 2017. For both tests, the distributions are Gaussian. Due to the normality of the data, the Z-test was used for data recorded throughout the year and the T-test for data recorded at the beginning of 2017 (uneq var. z: $0.71>0.48$ and uneq. var. t: $1.18>$ 0.26 , respectively). It was found that the differences between groupings of each sample are not significant, meaning that there are no expressive variations between the treatment efficiency values (with regard to the removal of organic load at the inlet and outlet of the treatment); therefore, no changes in effluent treatment were found due to the contribution of rainwater in the sewage collection system entering the activated sludge system.

Saliba and von Sperling (2017) found similar results for the performance of the activated sludge system organic load removal. The authors pointed out that, for a $515 \mathrm{~L} \mathrm{~s}^{-1}$ capacity treatment plant, the efficiency of this type of treatment is not influenced by intrusion of drainage water into the sewage collection system, despite the significant increase in flow between rainy and dry seasons. The study also highlighted that effluent indicator concentrations (chemical oxygen demand, biochemical oxygen demand, suspended solids, total suspended solids, nitrogen, nitrates, and phosphates) other than for ammonia, were reduced during the rainy season, indicating that the volume of water increased considerably due to the contribution of rainwater and would be sufficient to affect the treatment indicators.

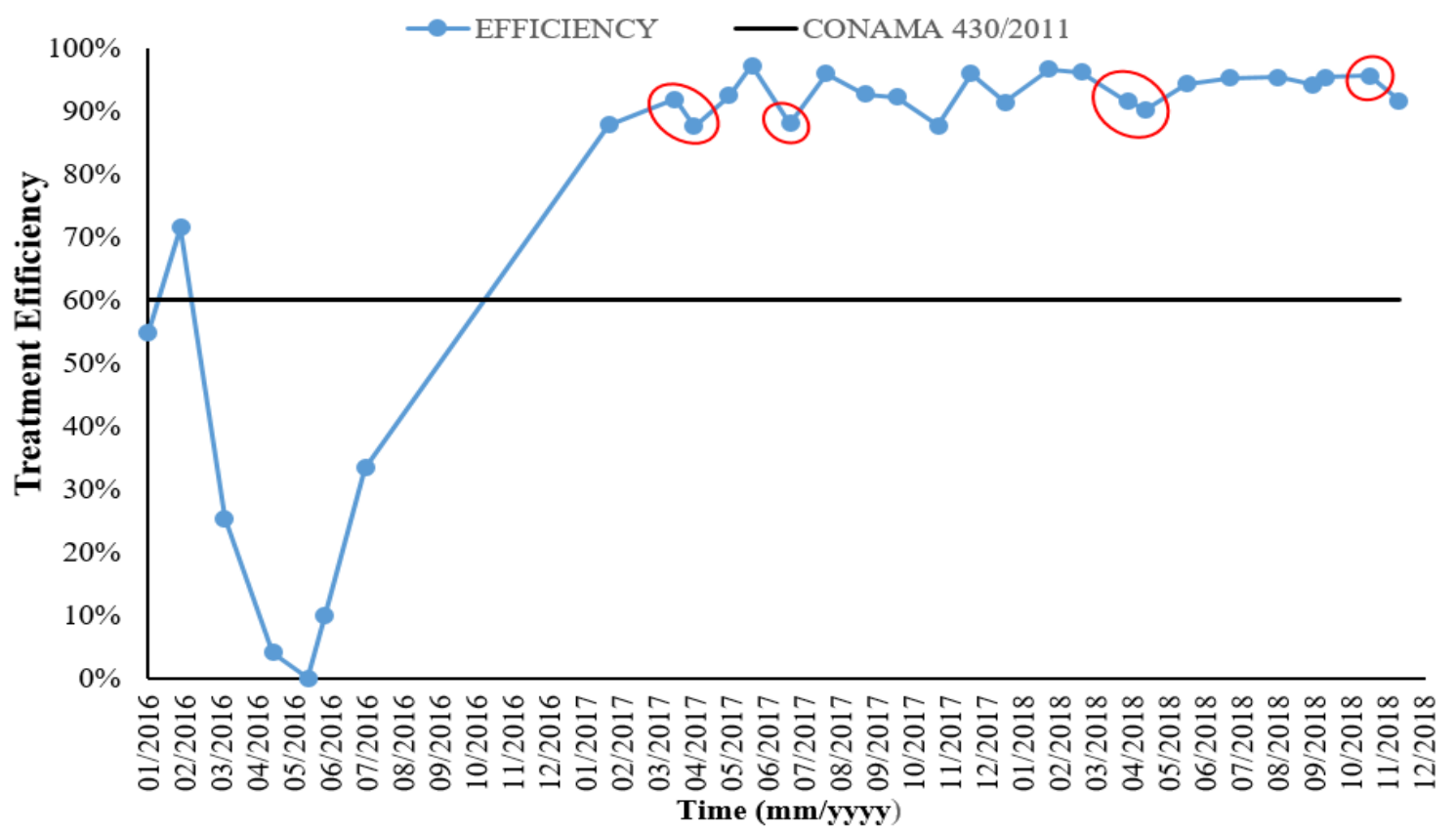

Figure 4. Efficiency in the treated effluent from the Janga WWTP, with rainy days highlighted in red.

For Rocha et al. (2016), influent controls are of great importance to the activated sludge system. The authors indicated that the bacterial colonies found in the sludge are directly responsible for the treatment and that several continuous impacts could easily alter the WWTP indicators, including stormwater intrusion, as it alters the stability of the system and of the biome found in the influent. The authors concluded that, for a medium-sized WWTP with an average capacity of $106 \mathrm{~L} \mathrm{~s}^{-1}$, approximately $25 \%$ of the capacity of the Janga WWTP, the incoming organic loads range from 180.24 to $393.82 \mathrm{mg} \mathrm{L}^{-1}$ and output ranges between 3 and $17.64 \mathrm{mg} \mathrm{L}^{-1}$, an average efficiency of $96.23 \%$, similar to what was found in this study $(93.15 \%)$ when the period of low efficiency is disregarded. Despite these changes, the bacterial colonies did not show signs of alteration, as there was no statistically significant change in the efficiency indicators of the treatment process. 


\section{CONCLUSIONS}

From what has been exposed in this study, it can be concluded that the results infer that there is a connection between the rainwater drainage systems and the sewage collection systems, as the inlet flow of the WWTP increases by about $25 \%$ when comparing the averages for rainy and dry days. During high rainfall-intensity events, halting the operation of the treatment plants helps to control the parameters of the influent that enters the station.

Rainfall slightly increases BOD concentrations in the influent and effluent. At the inlet of the WWTP, the temperature drop was significant on rainy days and the $\mathrm{pH}$ values were slightly alkalized. Nevertheless, these changes were insufficient to interfere with the efficiency of the treatment process.

Regarding the treatment efficiency of the WWTP, the data have normal distributions and did not show significant differences between dry and rainy days. Therefore, for the activated sludge treatment system in this study, the expressive increase in the volume of water that enters the system does not change its efficiency in treating the sewage.

\section{REFERENCES}

AHSAN, S.; RAHMAN, M. A.; KANECO, S.; KATSUMATRA, H.; SUZUKI, T.; OHTA, K. Effect of temperature on wastewater treatment with natural and waste materials. Clean Technologies and Environmental Policy, v. 7, p. 198-202, 2005. https://doi.org/10.1007/s10098-005-0271-5

ÁVILA, C.; SALAS, J. J.; MARTÍN, I.; ARAGÓN, C.; GARCÍA, J. Integrated treatment of combined sewer wastewater and stormwater in a hybrid constructed wetland system in southern Spain and its further reuse. Ecological Engineering, v. 50, p. 13-20, 2013. https://doi.org/10.1016/j.ecoleng.2012.08.009

BRAILE, P. M.; CAVALCANTI, J. E. W. A. Manual de tratamento de águas residuárias industriais. São Paulo: CETESB, 1993. 764 p.

BRANCO, M. A. T. P. Descargas não controladas de efluentes por efeito de afluências indevidas. $O$ caso de uma estação elevatória. 2015. 48p. Dissertação (Mestrado em Engenharia do Ambiente) - Faculdade de Engenharia, Universidade do Porto, Lisboa, 2015.

CHERNICARO, C. A. L.; VAN LIER, J. B.; NOYOLA, A.; RIBEIRO, T. B. Anaerobic sewage treatment: state of the art, constraints and challenges. Reviews in Environmental Science and Bio/Technology, v. 14, n. 4, p. 649-679, 2015. https://doi.org/10.1007/s11157-015-9377-3

CONAMA (Brasil). Resolução n ${ }^{\circ} 430$ de 13 de maio 2011. Dispõe sobre as condições e padrões de lançamento de efluentes, complementa e altera a Resolução no 357, de 17 de março de 2005, do Conselho Nacional do Meio Ambiente-CONAMA. Diário Oficial [da] União: seção 1, Brasília, DF, n. 92, p. 89, 16 maio 2011.

COSTA, I. G. C.; PIEROBON, F.; SOARES, E. C. A Efetivação do direito ao saneamento básico no Brasil: do PLANASA ao PLANASB. Meritum, v. 13, n. 2, p. 335-358, 2018.

GÓIS, F. A.; SOUZA, G. A.; OLIVEIRA, M. J.; LIMA, R. S.; KOSLOWSKI, L. A. D. Análise da qualidade da água quanto ao despejo industrial têxtil no rio dos índios. Revista Meio Ambiente e Sustentabilidade, v. 9, n. 5, p. 15-27, 2016. 
HAMMER, Ø.; HARPER, D. A. T.; RYAN P. D. PAST: paleontological statistics software package for education and data analysis. Palaeontologia Electronica, v. 4, n. 1, p. 1-9, 2001.

HOLANDA, M. A. C. R.; SOARES, W. A. Analysis of the effect of impermeability of urban soils on the infiltration of rainwater in the city of Recife, PE. Revista Ambiente \& Água, v. 14, n. 4, p. 1-10, 2019. https://doi.org/10.4136/ambi-agua.2386

JAMWAL, P.; ZUHAIL, T. Md.; URS, P. R.; SRINIVASAN, V.; LELE, S. Contribution of sewage treatment to pollution abatement of urban streams. Current Science, v. 108, n. 4, p. 677-685, 2015.

MAHAPATRA, D. M.; CHANAKYA, H. N.; RAMACHANDRA, T. V. Treatment efficacy of algae-based sewage treatment plants. Environmental Monitoring and Assessment, v. 9, n. 185, p. 7145-7164, 2013. https://doi.org/10.1007/s10661-013-3090-х

MINES, R. O.; LACKEY, L. W.; BEHREND, G. R.; The impact of rainfall on flows and loadings at Georgia's wastewater treatment plants. Water, Air, and Soil Pollution, v. 179, p. 135-157, 2007. https://doi.org/10.1007/s11270-006-9220-0

PIRATOBA, A. R. A.; RIBEIRO, H. M. C.; MORAlES, G. P.; GONCALVES, W. G. Caracterização de parâmetros de qualidade da água na área portuária de Barcarena, PA, Brasil. Revista Ambiente \& Água, v. 12, n. 3, p. 435-456, 2017. https://doi.org/10.4136/ambi-agua.1910

RIBEIRO, V. O.; PEIXOTO, M. S. Avaliação da contribuição pluvial parasitária no sistema de esgotamento sanitário efluente à ETE Guaxinim, Dourado/MS. Revista de engenharia e tecnologia, v. 10, n. 3, p. 144-155, 2018.

ROCHA, K. M.; SALAMONI, S. P.; SANTOS, R. H.; GOLDBACH, A. Monitoramento e avaliação de parâmetros físico-químicos e microbiológicos de uma estação de tratamento de efluentes com sistema de lodos ativados em uma agroindústria no meio oeste de Santa Catarina. Revista de Engenharia Civil IMED, v. 3, n. 1, p. 25-36, 2016. https://doi.org/10.18256/2358-6508/rec-imed.v3n1p25-36

SALIBA, P. D.; von SPERLING, M. Performance evaluation of a large sewage treatment plant in Brazil, consisting of a UASB reactor followed by activated sludge. Water Science $\boldsymbol{\&}$ Technology, v. 76, n. 8, 2017. https://doi.org/10.2166/wst.2017.284

SHATAT, M.; NAJAR, H. A. The impacts of temperature variation on wastewater treatment in the Gaza Strip. Gaza wastewater treatment plant as case study. In: WATER AND CLIMATE CHANGE IN THE MENA-REGION: ADAPTATION, MITIGATION, AND BEST PRACTICES, April 28-29, 2011, Berlin. Proceedings[...] Berlin: GIZ, 2011. p. $1-12$.

SENTURK, I.; BUYUKGUNGOR, H. Biohydrogen Production by Anaerobic Fermentation of Sewage Sludge - Effect of initial pH. Environmental and Ecology Research, v. 5, n. 2, p. 107-111, 2017. https://dx.doi.org/10.13189/eer.2017.050204

TONETTI, A. L.; CORAUCCI FILHO, B.; NICOLAU, C. E.; BARBOSA, M.; TONON, D. Tratamento de esgoto e produção de água de reuso com emprego de filtros de areia. Revista de Engenharia Sanitária e Ambiental, v. 17, n. 3, p. 287-294, 2012. https://doi.org/10.1590/S1413-41522012000300005 
WANDERLEY, L. S. A.; NÓBREGA, R. S.; MOREIRA, A. B.; ANJOS, R. S.; ALMEIDA, C. A. P. As chuvas na cidade do Recife: Uma climatologia de extremos. Revista $\begin{array}{lllllll}\text { Brasileira de } & \text { Climatologia, v. 22, p. }\end{array}$ http://dx.doi.org/10.5380/abclima.v22i0.56034

ZOPPAS, F. M.; BERNARDES, A. M.; MENEGUZZI, A. Parâmetros operacionais na remoção biológica de nitrogênio de águas por nitrificação e desnitrificação simultânea. Engenharia Sanitária e Ambiental, v. 21, n. 1, p. 29-42, 2016. https://doi.org/10.1590/S1413-41520201600100134682 